\title{
Inquiry-based Integrated Thematic Instruction On Character Education Of Primary School Students
}

Chumdari*, Sri Anitah, Budiyono, Nunuk Suryani

Postgraduate Program FKIP Universitas Sebelas Maret Surakarta, Indonesia

Corresponding author: Chumdari, E-mail: chumdari@staff.uns.ac.id

\section{ARTICLE INFO}

Article history

Received: April 03, 2018

Accepted: April 28, 2018

Published: April 30, 2018

Volume: 6 Issue: 2

Conflicts of interest: None

Funding: None

\begin{abstract}
This study aimed at investigating the differences between the yields of inquiry-based integrated thematic instruction and thematic instruction model on the character education of primary school students. The population was 253 elementary schools and 63,433 students in Surakarta City, Central Java, Indonesia. Samples were obtained through multistage cluster random sampling, which were then divided into experimental group (four classes, 129 students) and control group (four classes, 139 students). The Randomized Static Group Comparison Design was employed as the design of experiment. Data collection methods were interview, observation, questionnaire, and documentation. The instruments were validated by content validity and construct validity. Test for normality and homogeneity of data used Kolmogorov-Smirnov test and Levene Test. Data were analyzed using Mann-Whitney U Test. The result showed that students in the inquirybased integrated thematic group obtain better score (3.48) than those in the thematic group (3.28). Moreover, the mean rank of the first group (176.07) was also significantly higher than that of the second group (95.92) (Asymp. Sig. (2-tailed). 000<.05). In overall, inquiry-based integrated thematic instruction has more significant and positive contribution on the character education of primary school students in compared with the thematic instruction model.
\end{abstract}

Key words: Thematic Instruction Model, Inquiry-based Integrated Thematic Instruction, Character Values

\section{INTRODUCTION}

The National Education aims to develop the potential of learners to become persons who are faithful and pious to the one and only God, noble, healthy, knowledgeable, skillful, creative, independent, and democratic and responsible citizen (Law No. 20 of 2003 on National Education System). This purpose has covered almost the entire aspects of morals, noble character, and character values. Furthermore, primary school education should be organized optimally and systematically to attain such a purpose.

The Ministry of Education and Culture determines the learning objectives of primary school, which include knowledge, skills, and values and attitudes/characters, in which the achievement of learning outcomes varies based on the level of education. At primary level, attitude/character, psychomotor, cognitive aspect should cover, respectively, $60 \%, 30 \%$, and $10 \%$ of material in primary school (Kemendikbud, 2013; Marzano \& Bruner in Prastowo, 2015: p. 55). Learning process intended to knowledge and skills possession has been appropriate, yet the values and attitude/character education has been deemed suboptimal. In fact, character education at early level of education is crucial to promote students' commendable behaviors and good character in their future. It is an attempt to create civil society.

Character education has been implemented in primary schools in Indonesia. The approach is the integration of character values in learning activities through enculturating, exemplary, and conducive environment. Holistic approach is appropriate in which it requires teachers to serve as caregivers, models, and mentors; create a caring classroom environment; practice moral discipline; create democratic classroom environment; teach values through the curriculum; employ cooperative learning; promote conscience of the craft; encourage ethical reflection; teach conflict resolution; encourage awareness from class to outside activities; create a positive moral culture in school; and involve parents and communities in students moral development activities (Elkind \& Sweet, 2004; Lickona, 2013). Furthermore, teachers can implement one or more character education methods as mentioned above.

The characters fostered among learners in Elementary Schools include: (1) religious, (2) honest, (3) tolerant, (4) disciplined, (5) hard-working, (6) creative, (7) independent, (8) democratic, (9) curious, (10) bibliophilic, (11) responsible, (12) nationalistic, (13) patriotic, (14) appreciative, (15) friendly/communicative, (16) peaceful, 
(17) environmentally friendly, and (18) sociable (Aqib \& Sujak, 2011; Kemendikbud, 2011).

\section{Thematic Instruction}

Thematic instruction has been implemented in the first three grades of primary school since the enactment of the 2006 Curriculum. It is an integrated instruction that is initiated by a great idea, important or real and meaningful problem for students - who will use their knowledge and skills to answer questions or solve problems. Merickel (1998) and Parisot (n.d.) mentioned the concept of holistic approach as proposed by Piaget, Dewey, and Bruner. In integrated/thematic learning, the topics discussed are linked to the daily life of the students. They shall be simple, real and meaningful experiences to students. It is intended for the acquisition of integrated knowledge by students. It is distinctive from former problem-based learning, in which students are required to observe the phenomena around them, note those phenomena, and discuss those phenomena to seek solutions. The role of teacher is to guide students to question, prove assumptions, and listen to different opinions among them. This model provides opportunity for students to gain knowledge through direct experiences. The goal of problem-based learning is that students gain experience and problem-solving skills in daily life (Majid \& Rochman, 2014).

Thematic learning emphasizes on specific center of interest used to recognize symptoms and concepts from various disciplines (Mutohir et al., 1996, 1997). Wolfinger (1997) suggested integrated/thematic learning as a method of organizing the content of learning by utilizing the appropriate discipline or subjects to develop specific concept selected by the teacher (Anitah, 2009). Fogarty (1991) proposed ten models for integrating the curriculum in which some of them (Threaded, Integrated, Immersed and Networked) are interdisciplinary models, while thematic learning refers to Webbed model and integrated learning refers to Integrated model.

Majid and Rochman (2014) reasserted thematic learning is sourced from a particular center of interest to understand symptoms and concepts, either from relevant or less relevant disciplines. It can also be interpreted as an approach that links various fields of study - which reflect the real world around and within the range of the student's ability and development.

The characteristics of thematic learning are: 1). Student-centered, 2). Direct experiences, 3). Ambiguous distinction of subject matters, 4). Concepts from various subject matters, 5). Flexible, 6). Based on students' interests and needs, 7). Principle of fun learning while playing (Majid \& Rochman, 2014; Mutohir et al., 1976, 1977).

Thematic learning has several strengths since it promotes more comprehensive learning, student involvement, independence, flexibility, learning styles, problem solving, group activities, and various assessment techniques, as well as eliminates boundaries among disciplines. Additionally, Majid and Rochman (2014) also proposed the advantages of thematic learning, including: 1). In accordance with the phase of child development, 2). Selection of activities based on the student's interests and needs, 3). More meaningful learning activities and learning outcome, (4) Thinking skills exercise against problems in real world, 5). Pragmatic learning activities based on daily experience, 6). Jointly designed by teachers and students thus enhances cooperation among the involved parties as well as more enjoyable.

Nevertheless, Muhtadi (2011), Pudjiastuti (2011), Retnawati (2017) and Wolfinger (1997) argued the drawbacks of this model, including the less systematic skill and concepts sequence in the curriculum as a whole, complicated coordination among levels of themes, complex required documentation, protracted transition process toward the implementation, complex and continuous assessment with various techniques, and also various obstacles encountered by teachers during the [reparation and implementation of the model. Similarly, Tamassia and Renaat (2014) argued there is no scientific evidence of the effectiveness of integrated model in biology, chemistry and physics subjects in secondary schools on the scientific literacy. The main conclusion is just the implementation of model will be insufficient, insignificant, and ordinary. It implies the intellectual freedom for teachers and educators within the framework of the subject of Natural Science in constructing lesson plan. Additionally, John (2015) revealed that by applying the "new" thematic model, prospective teachers will be more effective in considering the student's need. Moreover, those with training will implement better the model in compared to those without any training.

In general, three stages are required in the implementation of thematic learning, namely the preparation, implementation, and evaluation. The linkage between the components of those stages in relation with character education in primary school is illustrated in Figure 1.

\section{Inquiry-based Integrated Thematic Instructional Model}

According to the 2013 Curriculum education in primary schools is directed toward the achievement of basic competencies of spiritual, social attitude, knowledge, and skill. Spiritual and social attitude competences affirm the compulsory of character education. To support those competencies, a variety of models, methods, media, and learning resources are employed based on the characteristics of learners and subjects. In addition to the integrated thematic instruction, process-oriented models are also required to enhance the scientific comprehension, among other inquiry-based, problem-based, and project-based approaches (Regulation of Ministry of Education and Culture No. 57/2014 and No. 103/2014).

As stated in Regulation of Ministry of Education and Culture No. 57 of 2014, the inquiry-based integrated thematic instructional model is a learning model that combines various competencies of various subjects in a variety of themes to provide a meaningful experience to the students (Kemendikbud, 2014). It also highlights the students' critical and analytical thinking process to seek and find answers to a question or solve a problem (Joyce, Weil \& Calhoun, 2011; Smith et al., 2007).

Kovalik (2014) suggested the effectiveness of integrated thematic instructional model. It facilitates the school 


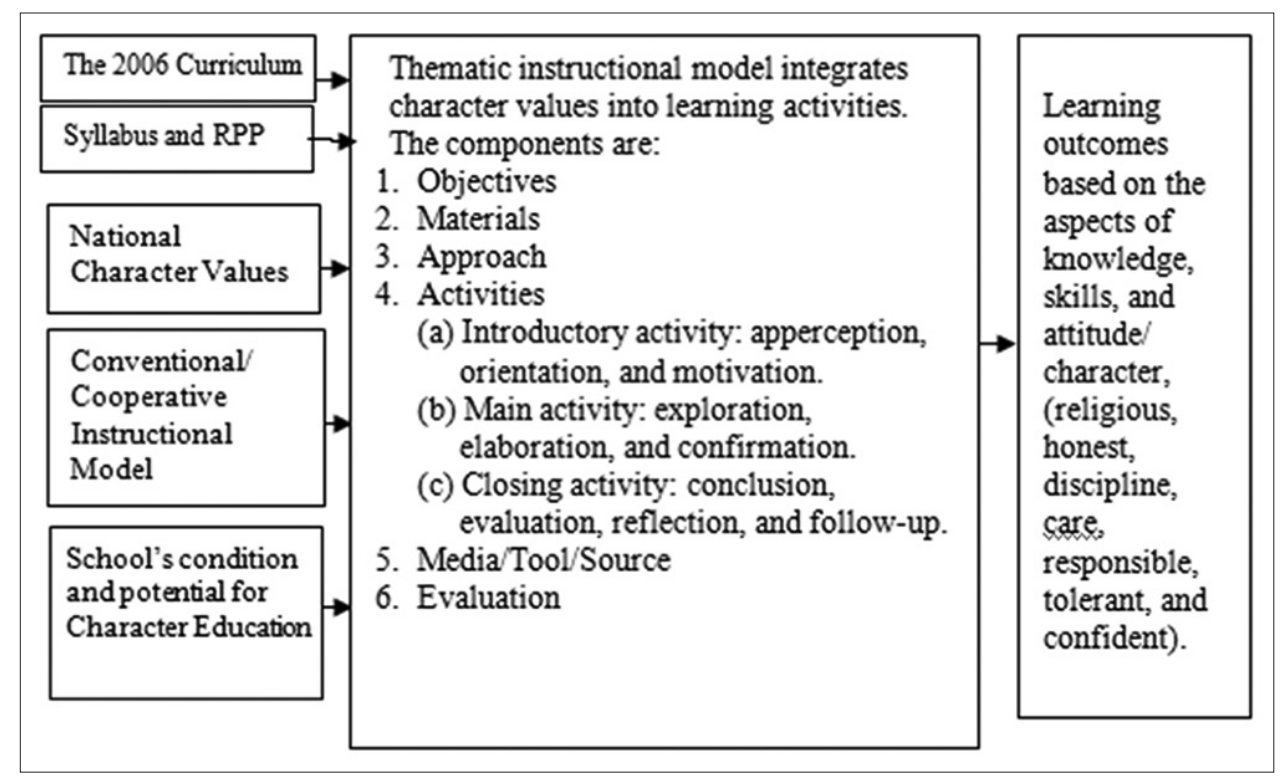

Figure 1: Relationship between the Components of Thematic Learning for Character Education

to promote democratic life and to meet the needs of the $21^{\text {st }}$ century. Smith et al. (2007) also claimed it as the best instructional method, which allows students to experience the process of knowledge creation. It is suitable and constructive for inculcating character values in primary school students.

Furthermore, the characteristics the combination of inquiry strategy and thematic learning include: 1 ). Child-centered, 2). Direct experiences, 3). Ambiguous distinction of subject matters, 4). Concepts from various subject matters, 5). Flexible, 6). Learning outcomes adjusted to students' interests and needs, 7). Principle of fun learning while playing, 8). Students' active and creative involvement, 9). Self-study skill improvement, 10). Constructive theory, and 11). Intellectual ability improvement (Sanjaya, 2007; Smith, 2007).

The strengths and weaknesses of the inquiry-based integrated thematic instructional model are also similar to those of thematic learning. The strengths include its emphasis on the development of cognitive, affective, and psychomotor aspects to encourage more meaningful learning, opportunity for students to learn according to their learning styles, suitability with modern learning psychological development, which considers learning as a process of behavior change thanks to experience, and suitability for students with higher average skills.

However, the implementation of inquiry-based model complicates the activity control and student performance. The preparation of lesson plan is also more difficult since it is not in accordance with the students' learning habits and teachers must adjust it to the available time (Sanjaya, 2007).

The implementation of the inquiry-based integrated thematic instructional model also consists of three stages, namely preparation, implementation and evaluation (Guidry, 2008; Joyce et al., 2009; Pedaste et al., 2015; Regulation of the Ministry of Education and Culture No. 22/2016; Sanjaya, 2007). The correlation of components in those stages is illustrated in Figure 2.

\section{Character Education in Learning}

Character education in primary school is carried out with integrated instructional model in which the achievement is reflected by the students' moral development. Kohlberg $(1958,1976,1986$, as cited in Djiwandono, 2009) and Santrock (2004) suggested such development is indicated by the augmented knowledge of children to distinguish and integrate self-perspective in making moral decisions. It is promoted by social experiences that generate cognitive conflicts, which occur in interactions with the environment and provide opportunities for them to recognize the perspective of others. The constructivist proposes learning as a process of constructing experience as a result of individual interaction with the environment. Reconstruction of understanding in learning through assimilation and accommodation occurs as an endeavor to cultivate the knowledge, skills, and values/character in learners. Assimilation and accommodation bring changes and new experiences.

Spiritual and social attitudes are the parameters of character assessment. Spiritual attitudes relate with regular with prayer, gratitude, pray before and after activities, and tolerant. Social attitudes include honest, disciplined, responsible, polite, care, and confident. Assessment of the learners' character is done through observation, self-assessment, peer-assessment, questionnaires, and teacher journal/documentation. The results are presented in scale from 1 to 4 (low to excellent).

The achievement of character education as learning outcomes depends on the learning system. Inquiry-based integrated thematic instruction is an innovative scientific learning model accentuated by the strengths of thematic learning which implementation uses conventional or cooperative model. The components of this model show better performance than the thematic model. Students are required to be active and creative and have high learning responsibilities than in conventional model. Meanwhile, teacher acts as facilitator and motivator where facilities and infrastructure, 


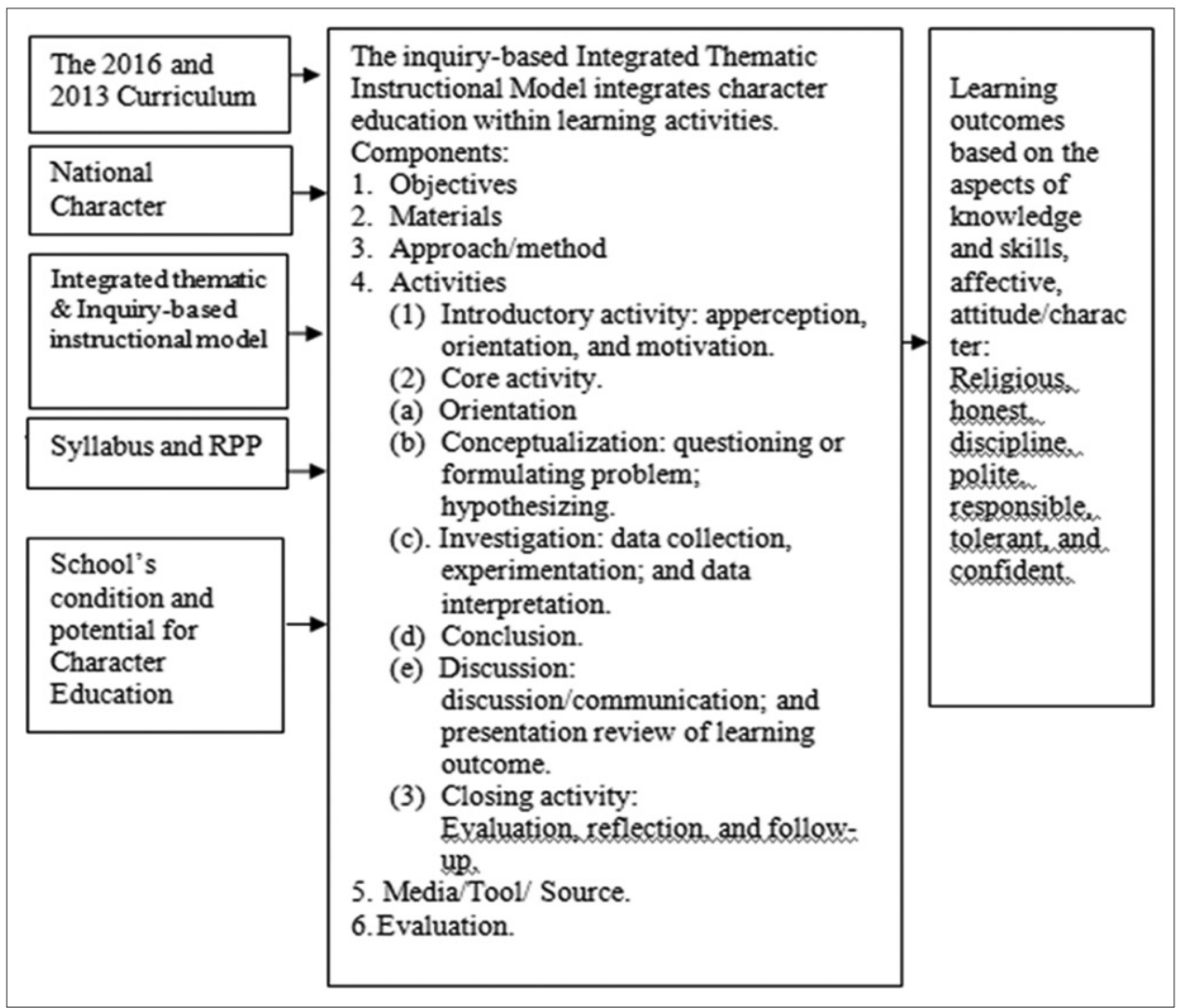

Figure 2: The Relationship between Components in Inquiry-based Integrated Thematic Learning for Character Education

tool/media and resources are either available or enriched. Moreover, it is equipped with authentic, comprehensive and sustainable assessment.

Henderson and Landesman (1995) affirmed that thematic/integrated learning in mathematics provides an equal positive effect to computing skills of students in both experimental and control group, and contributes to the achievement mathematics concept and application in experiment group. Soddart et al., (2002) also confirmed similar findings on Language and Natural Sciences, in which students in experiment group has better learning outcomes than the conventional fragmented model. Furthermore, Rustaman (2015) reported the students in integrated model class demonstrate better process skills than those in conventional group.

\section{Null Hypothesis}

The null hypothesis formulated based on previous is as follows:

$\mathrm{H}_{\mathrm{o}}$ : There is an insignificant difference between the effects of the inquiry-based integrated thematic instructional model and the thematic model on the character education of primary school students.

\section{RESEARCH METHOD}

\section{Sample}

This research was conducted at Elementary Schools in Surakarta, in April-July 2016. The population was 63,433 students from 253 schools. Multistage cluster random sampling technique was used. From five sub-districts in Surakarta, one sub-district was selected in which there are 53 schools in this sub-district. Eight classes from six schools were selected randomly, four classes from two very-high quality schools and four classes from four good quality schools. They were divided into experimental group (four classes, 129 students) and control group (four classes, 139 students).

\section{Instrument}

Instruments used to measure the learning outcome were questionnaires and observation sheets. Questionnaires were arranged based on a modified Likert scale with four scales of 1 to 4 . Three types of questionnaire were devised, each was distributed to teachers, students, and parents/guardian. Questionnaire validity test was carried out with content validity and construct validity. The content validity was based on the character values set forth in the guideline, or the suitability between the guideline and the parameters. Construct validity was carried out through expert judgment (Sugiyono, 2010). After the instrument was completed, it was taken to an expert. Experts provide assessment whether the instrument was eligible, eligible with revision, or not eligible. After the revision based on experts' recommendation is done, the instrument can be declared eligible (Budiyono, 2017).

Instrument testing with empirical validity test was performed through tray out method. Based on the results of tray out, questionnaire validity test is conducted by item analysis technique, namely by correlating between the score of items (X) with the total score (Y). If the correlation price is below 
0.30 , it can be concluded that the item is invalid and revision is required. If the correlation value is relatively high, of 0.30 or more, the question/statement is claimed to be valid (Sugiyono, 2010). If each item of the question/statement in the instrument is valid, the instrument as a whole is also valid. The instrument of reliability test is performed internally. Instrument reliability is tested by examining the correlation with the Alpha formula (Arikunto, 2014).

The results of the questionnaire validity test are: (1) Questionnaires about the character values for students amounted to 40 items, all of them are valid. The questionnaire reliability score was 0.883 ; (2) Questionnaire about the character values for students amounted to 30 items, all of them are valid. Reliability score was 0.891 ; (3) Questionnaire for teachers amounted to 40 items, all of them are valid. The reliability was 0.903 ; (4) Questionnaires for parents/guardian amounted to 40 items, all of them are valid. The questionnaire reliability score was 0.907 . Thus, the questionnaires consist of questionnaires of character values for students, for teachers, and for parents/guardian are all declared valid and reliable.

The experimental design was the Randomized Static Group Comparison Design as exemplified by Budiyono (2017). In this design, a group of subjects taken from a population are randomly divided into two groups, namely the experimental and control groups. The experimental group is subjected to a treatment variable $(\mathrm{X})$ within a certain period, while the control group is not. Subsequently, both groups are subjected to a specific measurement (i.e. $\mathrm{T}_{2}$ test). Differences between those groups are considered to be sourced from the treatment (Budiyono, 2017, p. 108). Prior to the treatment, both groups were tested in which the scores of questionnaire of the experimental and control group were 3.39 and 3.34, respectively. Subsequently, a Mann-Whitney U Test indicated that the score of the experimental group was higher $(M d n=3.375)$ than the score of control group $(M d n=3.336), U=7737.000, p=.05$, $r=.053$. Mean ranks of the experimental and control groups, respectively, were 144.02 and 125.66. Nevertheless, it showed those groups were insignificantly different prior to the treatment.

The inquiry-based integrated thematic instruction was implemented on the experimental group. The theme was selected, namely Animals and Plants, which consisted of three sub-themes of: Animals around me, Care for Animals, and Plants around me. This theme was conducted in six meetings, two meeting for each sub-theme. Each lesson included several subjects, i.e. Bahasa Indonesia, Civic education, Mathematics, Cultural arts education and skills, and Physical education sports and health. Meanwhile, the thematic instruction was implemented on the control group. It covered several themes, including: Events, Energy, Family, Health, and Manners. Each theme was discussed in a meeting, except Manners that was discussed twice. Thus totally there were six meetings. Those themes were incorporated into several subjects, i.e., Bahasa Indonesia, Civic education, Social sciences, Natural sciences, and Cultural arts education and Skills.

\section{Data Collection and Analysis Method}

Data were collected through observation, interview, questionnaire, and documentation. Observation was used to obtain data about the implementation of the instructional model's character values. Interviews with teachers were used to gain data about the condition of students related with the model implementation. Questionnaires were used to obtain data about the score of student's character. The instruments of data collection were: (1) Syllabus and lesson plan (RPP), student worksheets, and assessment instruments, (2) Lesson Planning Assessment Instrument (IPPP-1), (3) Lesson Implementation Assessment Instrument (IPPP-2), (4) Observation sheets of character values achievement, (5) Questionnaire about the student character values, (6) field notes. Content validity and construct validity were used to validate instruments, namely through experts judgment. Questionnaire was tested by empirical testing or tryouts (Budiyono, 2017; Sugiyono, 2010).

\section{Data Analysis}

Data analysis to test the hypothesis was done by non-parametric statistical technique, which was Mann-Whitney U Test. Prior to data analysis, normality test and homogeneity of data were performed with Kolmogorov-Smirnov test and Levene test (Sugiyono, 2010; Wiersma, 2000).

\section{RESULTS}

The results of the implementation of instructional models on the achievement of character education in primary school students are presented as follows:

1. The Implementation of Thematic Instructional Model in Elementary Schools in Surakarta

Table 1 shows the Mean score of the implementation of thematic learning in the control group is 83. It is classified in good category that implies the appropriate implementation of lesson plan.

Table 2 demonstrates the mean score of the character education of students in the control group is 3.28 , which is classified as good or in progress.

2. The Implementation of Inquiry-based Integrated Thematic Instructional Model on Experiment Group.

\section{The Implementation of Inquiry-based Integrated Thematic Instructional Model on Experiment Group.}

Table 3 shows the mean score of RPP implementation is 92, which is very good. It indicates the implementation of an inquiry-based integrated thematic instructional model is done very well.

Table 4 demonstrates the mean score of character education of students in experimental group is 3.48 , which is classified in very good category.

Table 5 shows the recapitulation of the score of students' character education. In general, the experimental group has higher score compared to the score gained by the control group. The highest score of experimental group and control group is 3.90 and 3.58 , respectively. Furthermore, the mean scores are 3.48 and 3.28 , respectively. 
Table 1. Score of RPP and Its Implementation on Control Group

\begin{tabular}{lccccc}
\hline Meeting & Score of RPP & $\begin{array}{c}\text { Score of RPP } \\
\text { implementation }\end{array}$ & $\begin{array}{c}\text { Total } \\
\text { score }\end{array}$ & $\begin{array}{c}\text { Conversion } \\
\text { Scale 0-100 }\end{array}$ & Category \\
\hline $1^{\text {st }}$ & 61 & 116 & 177 & 77 & Good \\
$2^{\text {nd }}$ & 63 & 117 & 180 & 78 & Good \\
$3^{\text {rd }}$ & 66 & 119 & 185 & 80 & Good \\
$4^{\text {th }}$ & 67 & 121 & 188 & 82 & Good \\
$5^{\text {th }}$ & 72 & 131 & 203 & 88 & Excellent \\
$6^{\text {th }}$ & 74 & 137 & 211 & 92 & Excellent \\
Total & 403 & 741 & 1144 & 497 & Good \\
Mean & 67.2 & 123.5 & 191 & 83 & \\
\hline
\end{tabular}

Description: Maximum score of RPP $=80$; Maximum score of RPP implementation $=150$; Total maximum score $=230$.

Table 2. Score of Character Education of Students in Control Group

\begin{tabular}{lccccc}
\hline Interval & Median & Frequency & $\begin{array}{c}\text { Frequency* } \\
\text { median }\end{array}$ & $\begin{array}{c}\text { Mean } \\
\text { percentage }\end{array}$ & $\begin{array}{c}\text { Cumulative } \\
\text { frequency }\end{array}$ \\
\hline $3.00-3.09$ & 3.05 & 9 & 27.5 & 6.5 & 6.5 \\
$3.10-3.19$ & 3.15 & 23 & 72.5 & 16.5 & 23.0 \\
$3.20-3.29$ & 3.25 & 33 & 107.3 & 23.7 & 46.8 \\
$3.30-3.39$ & 3.35 & 58 & 194.3 & 41.7 & 88.5 \\
$3.40-3.49$ & 3.45 & 13 & 44.9 & 9.4 & 97.8 \\
$3.50-3.59$ & 3.55 & 3 & 10.7 & 2.2 & 100.0 \\
Total & & 139 & 457 & 100 & 100 \\
Mean & & & 3.28 & & \\
\hline
\end{tabular}

Table 3. Score of RPP and Its Implementation on Experimental Group

\begin{tabular}{lccccc}
\hline Meeting & $\begin{array}{c}\text { Score of Lesson } \\
\text { Plan }\end{array}$ & $\begin{array}{c}\text { Score of Lesson Plan } \\
\text { implementation }\end{array}$ & $\begin{array}{c}\text { Total } \\
\text { score }\end{array}$ & $\begin{array}{c}\text { Conversion } \\
\text { scale 0-100 }\end{array}$ & Category \\
\hline $1^{\text {st }}$ & 70 & 136 & 206 & 89 & Excellent \\
$2^{\text {nd }}$ & 73 & 134 & 207 & 90 & Excellent \\
$3^{\text {rd }}$ & 73 & 133 & 206 & 90 & Excellent \\
$4^{\text {th }}$ & 74 & 140 & 214 & 93 & Excellent \\
$5^{\text {th }}$ & 75 & 140 & 215 & 93 & Excellent \\
$6^{\text {th }}$ & 75 & 143 & 218 & 95 & Excellent \\
Mean & 73 & 139 & 220 & 92 & Excellent \\
\hline
\end{tabular}

Description: Maximum score of lesson plan = 80; Maximum score of lesson plan =150; Total maximum score $=230$.

Table 4. Score of Character Education of Students in Experimental Group

\begin{tabular}{lccccc}
\hline Interval & Median & Frequency & $\begin{array}{c}\text { Frequency mulplied } \\
\text { median }\end{array}$ & $\begin{array}{c}\text { Mean } \\
\text { percentage }\end{array}$ & $\begin{array}{c}\text { Cumulative } \\
\text { frequency }\end{array}$ \\
\hline $2.80-2.99$ & 2.90 & 2 & 5.8 & 1.6 & 1.6 \\
$3.00-3.19$ & 3.10 & 11 & 34.1 & 8.5 & 10.1 \\
$3.20-3.39$ & 3.30 & 33 & 108.9 & 25.6 & 35.7 \\
$3.40-3.59$ & 3.50 & 39 & 136.5 & 30.2 & 65.9 \\
$3.60-3.79$ & 3.70 & 40 & 148.0 & 31.0 & 96.9 \\
$3.80-3.99$ & 3.90 & 4 & 15.6 & 3.1 & 100.0 \\
Total & & 129 & 449 & 100 & 100 \\
Mean & & & 3.48 & & \\
\hline
\end{tabular}


Table 5. Recapitulation of Character Education Score of Students in Experimental and Control Group

\begin{tabular}{lccccc}
\hline Subject/Group & Student $(\mathbf{N})$ & Score & $\begin{array}{c}\text { Highest } \\
\text { score }\end{array}$ & $\begin{array}{c}\text { Lowest } \\
\text { score }\end{array}$ & Mean \\
\hline Experimental & 129 & 449.82 & 3.90 & 2.79 & 3.48 \\
Control & 139 & 456.30 & 3.58 & 3.01 & 3.28 \\
Total & 268 & 906.12 & - & - & - \\
\hline
\end{tabular}

\section{Data Analysis}

(1) Result of normality test and homogeneity of research data

The normality test was conducted using Kolmogorov-Smirnov test. The result of experimental group was Sig. 200>.05, which implies the normal distribution of score in experimental group. Meanwhile, the result of control group was Sig. $003<.05$, which indicates the score is not distributed normally.

The homogeneity of data was tested using SPSS 17 with Levene Test technique. The result was $p=.000<.05$, which means the scores between the experimental and control group was not homogeneous.

(2) Null Hypothesis $\left(\mathrm{H}_{\mathrm{o}}\right)$ and Alternative Hypothesis $\left(\mathrm{H}_{\mathrm{a}}\right)$ $\mathrm{H}_{\mathrm{o}}=$ There is insignificant difference between the effect of thematic instruction and inquiry-based integrated thematic instruction on the achievement of character education of primary school students.

$\mathrm{H}_{\mathrm{a}}=$ The inquiry-based integrated thematic instruction has more significant and positive contribution to the achievement of character education on primary school students in compared with thematic instruction.

(3) The significance level was $\alpha=.05$ (5\%).

(4) In hypothesis testing, Mann-Whitney Test was used to compare differences between two data groups of students' score.

(5) Hypothesis testing.

Data processing using SPSS 17 with Mann-Whitney U Test obtained the result of the experimental group $(M d n=$ 3.513) and control group $(M d n=3.299), U=3603.000, r$ $=.000$ (Asymp. Sig. (2-tailed).000<.05). Thus, $\mathrm{H}_{\mathrm{o}}$ was rejected and $\mathrm{H}_{\mathrm{a}}$ was accepted. It can be concluded that there is a significant difference between the scores of students in the experimental group (3.48) and in control group (3.28). Based on the Mean Rank, the experimental group obtained 176.07, which is significantly higher than that of the control group (95.92). Hence, it can be concluded that the inquiry-based integrated thematic instruction contributes significantly more to the achievement of character education compared with the thematic instruction model.

\section{DISCUSSION}

The results of this study revealed the significant effect of the inquiry-based integrated thematic instructional model than the thematic model toward on the achievement of character education in elementary school. Moreover, it also confirmed the theories underlying the integrated thematic model and the inquiry-based instructional model. Kovalik (2014) asserted the effectiveness of integrated thematic instructional model. Moreover, it is constructive in guide students to possess knowledge. Inquiry-based strategy leads students to independently gain information or knowledge (Smith, 2007). The main difference is the inquiry-based integrated thematic instructional model combines the models, while the integrated thematic model as well as inquiry model is a single model as stated by Kovalik (2014).

The results of this study were in accordance with several reported findings. Henderson and Landesman (1995) emphasized that: (1) The integrated thematic learning model in Mathematics provides an equally positive influence on students' computing skills in the experimental and control groups, (2) The Integrated thematic learning model in Mathematics provides better influence to achievement on concept and application of Mathematics in experiment group than on control group. Similarly, this present study also revealed the positive and significant influence of integrated thematic instructional model on to student's learning outcomes. Furthermore, the inquiry-based integrated thematic instruction model as the independent variable of the present study was different from that of Henderson and Landesman (1995), which was the integrated thematic model in Mathematics. The dependent variables of this present research were character values, while the dependent variables in Henderson and Landesman (1995) were computational skills, and achievement on mathematical concepts and applications.

The findings of this study were also in accordance with those reported by Soddart et al. (2002). It concluded that inquiry-based integrated learning in Language and Natural Science subjects provided better learning outcomes than conventional models that separate the language lesson from science. The suitability with this present study was the similar independent variable of inquiry-based thematic integrated learning model. This independent variable provided a positive and significant effect on student learning outcomes. The difference was the learning outcome of the present study was character values, while in Soddart et al. (2002), the outcome was general or academic learning outcomes. In addition, the present study compared the inquiry-based integrated thematic instructional model with the thematic model, whereas Soddart et al. (2002) compared the inquiry-based integrated model of Language and Natural Science with the traditional or direct model.

This study also supported the findings reported by Rustaman (2015) in which the experimental group with the treatment of inquiry model showed higher process skills than conventional control class. The relevance of this present study with Rustaman was the positive and significant influence of independent variable on learning outcome. The dissimilarity was the independent variable of this present study was the inquiry-based integrated thematic instructional model, while Rustaman (2015) used the inquiry model. 
The dependent variable of this present study was the character values while the dependent variable in Rustaman was the process absorption.

The results of this study were also in accordance with the results reported by Witt and Ulmer (2010), who concluded that the implementation of inquiry-based instructional model affects the student's academic achievement. Inquiry-based learning was more effective in improving students' academic performance than traditional models. The relevance of this present study to Witt and Ulmer was the independent variables of inquiry-based integrated thematic model and inquiry model have positive and significant influence to the dependent variable, namely the students' character and the students' academic achievement. The difference was on the independent variable of this study, which was inquiry-based integrated thematic instructional model, while the independent variable of Witt and Ulmer was inquiry model. Moreover, the dependent variable of Witt and Ulmer was the student's academic achievement.

The results of this study also supported the study of John (2015) in which by applying new thematic models, prospective teachers would be more effective in providing the students' aspirations. Implementation of integrated curriculum by prospective teachers who had training was also better compared to those without any training. The similarity with the present study was on the effectiveness of integrated thematic model on the learning outcomes. The difference was on the independent and dependent variables, which were integrated model and the learning requirement of students, respectively.

Furthermore, the results of this study opposed the study carried out by Tamassia and Renaat (2014) who argued there was no scientific evidence of the effectiveness of integrated model in biology, chemistry and physics subjects in secondary schools toward scientific literacy. It concluded that the practice of the model alone would be inadequate, ineffective, and not extraordinary. It implied the significance of the intellectual freedom of teachers and educators within the framework of the subject of Natural Science in learning construction. Likewise, Retnawati et al. (2017) also reported that teachers encountered obstacles in selecting appropriate problems and themes within thematic, scientific and problem-based learning and in managing time for project-based learning. It was mainly caused by the limited availability of learning facilities and the insufficient teachers' capacity in selecting appropriate assessment techniques, creating good instruments and formulating clear assessment criteria.

The obstacle encountered by teachers was also the problem found by Amalina, Anitah and Riyadi (2018). It related with teachers' difficulty to manage the class and obtain thematic-related guidelines. Moreover, Muhtadi (2011) suggested about $80 \%$ of elementary school teachers in Yogyakarta City, Indonesia, were not ready to implement the character education curriculum due to their lack of ability in developing strategies in the class, the lack of socialization from the education office, and the lack of support from the principal. Pujiastuti (2011) also disclosed the problems related with thematic learning implementation including those linked to the preparation stage (i.e. teacher's difficulty in elaborating the Competency Standards and Basic Competencies into indicators, developing themes and examples, mapping the basic competencies, and formulating the integration of various meta lessons in RPP), the implementation stage (i.e., limited knowledge and ability of teachers as well as limited teaching materials, learning facilities and infrastructure), and the assessment stage (i.e. difficulty in performing assessment for students in grade 1 since they have not read and written well, difficulty in documentation, difficulty in devising assessment instruments, and difficulty in determining the results of thematic learning since the assessment is based on each subject).

\section{CONCLUSION AND IMPLICATIONS}

This study found out that the implementation of inquiry-based integrated thematic instruction can be done very well. Data analysis with Mann-Whitney Test revealed the score of students in inquiry-based integrated thematic group is better than those in thematic group. Based on the Mean Rank, the score of the first group is also better than those in second group. In overall, the learning outcomes of student's character education supported by the implementation of inquiry-based integrated thematic instruction are more significant and positive compared with those with thematic learning. This model is recommended to promote the character values of primary school students.

Based on the results of data analysis with descriptive statistical techniques, it can be concluded that the implementation of inquiry-based integrated thematic instructional model is effective. From result of data analysis with Mann-Whitney U Test, the Mean rank of the score of students in inquiry-based integrated thematic group is better than those in control group $(176.07>95.92$, Asymp. Sig. (2-tailed). $000<.05)$. Test obtained the result of the experimental group $(M d n=3.513)$ and control group $(M d n=3.299)$, $U=3603.000, r=.000$ (Asymp. Sig. (2-tailed).000<.05). The score indicates the significant different learning outcomes between those groups. In overall, the learning outcomes of student's character education supported by the implementation of inquiry-based integrated thematic instruction is more significant and positive in compared with those with thematic learning. This model is recommended to promote the character values of primary school students.

The theoretical implication of this study is to enhance the discourse in the methodology of instructional in particular, and the science of education in general. The practical implication of this study is to provide empirical evidence of the effectiveness of inquiry-based integrated thematic model and an alternative for effective learning to attain character education learning outcomes, as well as the aspects of knowledge and skills.

It is suggested for primary school teachers to use an inquiry-based integrated thematic model to improve the learning outcomes of the students' character values or affective aspects, and the learning outcomes of the knowledge and skills in general. Furthermore, the Government, particularly the Ministry of Education shall formulate a comprehensive 
inquiry-based thematic learning curriculum equipped with its additional tools in which each subject is devised based on inquiry, particularly in accordance with the surrounding. Wider and deeper scope is recommended for future researchers.

\section{REFERENCES}

Amaliana, U. A., Anitah, S., \& Riyadi. (2018). A qualitative phenomenological exploration of thematic learning in elementary school. International Journal of Education Research Review. Retrieved from https://goo.gl/BzHQ2o

Anitah, S. (2009). Teknologi Pembelajaran. Surakarta: Learning Resource Centre Faculty of Teacher Training and Education UNS.

Aqib, Z. \& Sujak. (2011). Panduan \& Aplikasi Pendidikan Karakter. Bandung: Yrama Widya.

Arikunto, S. (2014). Prosedur Penelitian, Suatu Pendekatan Praktik, Jakarta: PT. Rineka Cipta.

Blanchard, M. R. Southerland, S. A. Osborne, J. W. Sampson, V. D. Anetta, L. A., \& Granger, E. M. (2010). Is inquiry possible in light of accountability?: A quantitative comparison of the relative effectiveness of guided inquiry and verification laboratory instruction. Science Education, 94(4), 576-596.

Budiyono. (2017). Pengantar Metodologi Penelitian Pendidikan. Surakarta: UNS Press.

Depdiknas, (2003). Undang-Undang RI nomor 20, tahun 2003, tentang Sistem Pendidikan Nasional.

Djiwandono, S.E.W. (2009). Psikologi Pendidikan. Jakarta: PT. Gramedia Widiasarana Indonesia.

Elkind, D. H. \& Sweet, F. (2004). How to do character education. Retrieved from http://www.goodcharacter.com/ article 4.html.

Fogarty, R. (1991). How to integrate curricula. Illinois: Skylight Publishing Inc.

Fogarty, R. (1991). The association for supervision and curriculum development, ten ways to integrate curriculum. educational leadership, 49(2), 61-65. Retrieved from https://goo.gl/tMuiM1

Guidry, A. O. (2008). Character education through a reflective moral inquiry: A revised model that answers old questions. Journal of Curriculum and Instruction (JoCI), 2(1). Retrieved from http://www.joci.ecu.edu

Henderson, R. W. \& Landesman, E. M. (1995). Effects of thematically integrated mathematic instruction on students of Mexican descent. Journal of Educational Research, 88, 290-300.

John, Y. J. (2015). A “new” thematic, integrated curriculum for primary schools of Trinidad and Tobago: A paradigm shift. International Journal of Higher Education, 4(3), 172-187. Retrieved from http://www.sciedupress. com/ ijhe.

Joyce, B., Weil, M. \& Calhoun, E. (2011). Models of teaching. Model-model pengajaran, $8^{\text {th }} \mathrm{Ed}$. [Trans. Achmad Fawaid \& Ateilla Mirza). Yogyakarta: Pustaka Pelajar.

Kemendikbud RI. (2011). Pendidikan Karakter untuk Membangun Karakter Bangsa. Jakarta: Direktorat Jenderal Pendidikan Dasar.
Kemendikbud RI. (2013). Kerangka Dasar dan Struktur Kurikulum 2013.

Kemendikbud RI. (2014). Peraturan Menteri Pendidikan dan Kebudayaan Republik Indonesia No 57 Tahun 2014

Tentang Kurikulum 2013 Sekolah Dasar/Madrasah Ibtidaiyan.

Kovalik, S. J. (2014). Integration of the disciplines, integrated thematic instruction model. Retrieved from https:// goo.gl/x3xePu

Lickona, T. (2013). Pendidikan Karakter, Panduan Lengkap Mendidik Siswa menjadi Pintar dan Baik. (Trans. Lita S). Bandung: Penerbit Nusa Media.

Majid, A. \& Rochman, C. (2014). Pendekatan Ilmiah Dalam Implementasi Kurikulum 2013. Bandung: PT Remaja Rosdakarya.

McDaniel, A. K. (1998). Character education: developing effective programs. Retrieved from http://www.joe.org/ joe/1998april/a3.php.

Merickel, M. L. (1998). Integration of the disciplines, integrated thematic instruction model. Retrieved from http:// www.thecenter4learning.com/html/\%20about_\%20us/ itimodel.\%20htm.

Muhtadi, Ali. et. al. (2011). Kesiapan Guru SD Di Kotamadya Yogyakarta Untuk Mengimplementasikan Kurikulum Pendidikan Karakter. Research Report (Unpublished). Fakultas Ilmu Pendidikan Universitas Negeri Yogyakarta.

Mutohir, T. C., Kartadinata, S., Zuchdi, D., Wahab, A. A., Herawati, I. S., Prabowo. (1996,1997). Pembelajaran Terpadu Untuk PGSD. Jakarta: Ditjen Dikti, BP3GSD.

Parisot, A. (n.d.). Integrated instruction: What it is, why it is important and how it works!. American Career Educational Programs, 2-4. Retrieved from http://www. carcom.com.

Pedaste, M., Maeots, M., Siiman, L. A., de Jong, T., van Riesen, S. A. N., Kamp, E. T., Manoli, C. C., Zacharia, Z. C. \& Tsourlidaki, E. (2015). Phases of inquiry-based learning: Definition and the inquiry cycle. Elsevier. Educational Research Review, 14, 47-61. Retrieved from www.elsevier.com/locate/edurev.

Prastowo, A. (2015). Menyusun Rencana Pelaksanaan Pembelajaran (RPP) Tematik Terpadu, Implementasi Kurikulum 2013 untuk SD/MI. Jakarta: Pranadamedia Group.

Pudjiastuti, A. (2011). Permasalahan Penerapan Pembelajaran Tematik di Kelas Awal Sekolah Dasar (online). Disertasi Program Studi Teknologi Pembelajaran, Program Pascasarjana, Universitas Negeri Malang. Retrieved from http://karya-ilmiah.um.ac.id/index.php/ disertasi/article/view/10880

Retnawati, H., Munadi, S., Arlinwibowo, J., Wulandari, N. F. \& Sulistyaningsih, E. (2017). Teachers' difficulties in implementing thematic teaching and learning in elementary schools. The New Educational Review, 48.

Rustaman, N. Y. (2015). Perkembangan penelitian pembelajaran berbasis inkuiri dalam pendidikan sains. Paper presented in Seminar Nasional II Himpunan Ikatan Sarjana dan Pemerhati Pendidikan IPA Indonesia in collaboration with FPMIPA UPI Bandung, 22-23 Juli 2005, 
FPMIPA UPI. Retrieved from www.nrustaman@upi. edu/ipa-05.

Sanjaya, W. (2007). Strategi Pembelajaran Berorientasi Standar Proses Pendidikan. Jakarta: Kencana.

Santrock, J. W. (2004). A Topical Approach to Life-Span Development ( $2^{\text {nd }}$ ed.). Singapore: McGraw Hill.

Smith, R. S. (2007). Experiencing the process of knowledge creation: The nature and use of inquiry-based learning in higher education. University of Otego, New Zealand. Retrieved from https://goo.gl/JJeLGp

Smith, R. S., Helen, M. T. A., Billy, O., \& Jane, R. (2007). How Effective is Inquiry-Based Learning in Linking Teaching and Research? Paper prepared for International Colloquium on International Policies and Practices for Academic Inquiry. Retrieved from https://goo. $\mathrm{gl} / \mathrm{aom} 8 \mathrm{XN}$

Soddart, T., Pinal, A., Latzke, M., \& Canaday, D. (2002). Integrating inquiry science and language development for English language learners. Journal of Research in Sci- ence Teaching, 39(8), 664-687. Retrieved from https:// goo.gl/gS2MV1

Sugiyono. (2010). Metode Penelitian Pendidikan (Pendekatan Kuantitatif, Kualitatif, dan R\&D). Bandung: Alfabeta.

Tamassia, L., \& Renaat, F. (2014). Does integrated science education improve scientific literacy? Journal of the European Teacher Education Network, 9, 131-141. Retrieved from https://www.jeten-online.org/index: php:/ jeten/article/download/44/39.

Wiersma, W. (2000). Research Methods in Education an Introduction. Singapore: Allyn and Bacon.

Witt, C., \& Ulmer, J. (2010). The Impact of Inquiry-Based Learning on the Academic Achievement of Middle School Students. Western AAAE Research Conference Proceedings 269. Retrieved from http://www.academia. edu/724764.

Wolfinger, D. M., \& Stockard, J. W. (1997). Elementary Method: An Integrated Curriculum. New York: Longman. 